\title{
Conceptual Model of the Education Management Information System for Higher Education Institutions
}

\author{
Utkir Khamdamov $^{1}$, Alisher Abdullayev ${ }^{2}$, Jamshid Elov $^{1}$, Djamshid Sultanov ${ }^{1}$ \\ ${ }^{1}$ Department of Hardware and software of management systems in telecommunication, Tashkent university of information \\ technologies named after Muhammad al-Khwarizmi, Tashkent, Uzbekistan. utkir.hamdamov@ mail.ru, elov.jamshid@ gmail.com, \\ sdjamshid@gmail.com \\ ${ }^{2}$ Department for development of information and communication technologies, Ministry of higher and secondary specialized \\ education of the Republic of Uzbekistan, Tashkent, Uzbekistan. depit@edu.uz
}

\begin{abstract}
This paper describes the role and features of using automated information systems in the activities of higher educational institutions, as well as an overview of existing information systems in the field of education. The concept and approaches of introducing electronic education information services for students, teachers and administrative staff, as well as the information system of higher education management in the Republic of Uzbekistan, are described. The higher education management information system covers all tasks related to the administrative, academic, scientific, financial and economic activities of educational institutions. The paper considers the particular characteristics of the education management and processes in Uzbekistan. Accordingly, the re-engineering of the business processes and workflow of the administrative and managerial aspects are designed. Finally, current research wraps up that traditional education management processes can be transferred to the e-services using promising opportunities of the information systems.
\end{abstract}

Key words: Academic activity, Educational process automation, Education management IS, Process reengineering

\section{INTRODUCTION}

The widespread use of information and communication technologies (ICT) is a global trend in world development. The use of modern technologies for information processing and transmission is crucial to increase the competitiveness of the economy and expand its capabilities for integration into the world economy, to increase the efficiency of public administration processes at all levels of government, such as at the local government level, in the state and non-state sectors of the economy [1].

Higher education coverage in Uzbekistan is rapidly increasing for the last 5 years, which more than 264000 students were consuming services of higher education institutions of the country in 2017 [3]. Besides that, the government of Uzbekistan has initiated to increase the quotas for the yearly enrolment by establishing new higher educational institutions and modernizing existing ones. Accordingly, higher education management has been staying with the need for widely implementing information and communication technologies for the administrative processes. The Department for the Development of Information and Communication Technologies, together with the Center for Implementation of E-Learning in Educational Institutions under the Ministry of Higher and secondary special education, is engaged in the development of informatization and information technologies in the higher education system. The main functions of the Department and Center are the coordination and implementation of modern technologies and training systems using ICT in the educational process.

The introduction of information technologies in the field of education allows us to provide electronic information services which aimed at meeting the information needs of students and teachers by providing electronic data. The main objectives of electronic services are to increase the reliability and improvement of the activities of the higher education system, as well as providing necessary electronic education services and information to students, teachers and other interested parties [2], [11]-[13].

Currently, large-scale reforms in the field of information and communication technologies are being implemented in the Republic and the system of higher and secondary specialized education. Following the Presidential decree of the Republic of Uzbekistan "On the organization of the National electronic education network in the Republic of Uzbekistan" PP-1740 of April 16, 2012, the Republic established a national network of electronic education, which became the first among the countries of Central Asia. Today, this network includes more than 160 sites with high-speed data access. Based on the network there are more than 15 information systems used together with higher educational institutions (HEI). Through the network-based video conferencing system, online lessons, training and management sessions are held [3]. 
In the field of higher education, certain work is also underway to implement information systems and form educational databases to automate administrative processes and translate educational services into the interactive form. However, the existing technical ICT infrastructure and wireless access infrastructure do not meet the requirements for performance, fault tolerance and security, also do not allow the introduction of modern educational information services.

Today, it is necessary to implement the Higher Education Management Information System (HEMIS) for the timely and high-quality planning of HEI administrative, educational, scientific, economic and financial activities, monitoring the fulfilment of the educational institution's target tasks, as well as for electronic data exchange between the participants of the educational process in the higher education system. The use of specialized information systems in the field of higher education will allow for the comprehensive automation of the activities of higher educational institutions, the formation of a single database of all types of higher educational institutions at the republican level, to form a database of the contingent of students, teachers and administrative personnel of higher educational institutions, to monitor the administrative, educational, scientific and financial activities of higher educational institutions. [4], [14], [15].

The most common type of information systems (IS) at the present stage of the development of information and communication technologies are automated information systems (AIS). An automated information system is understood as an orderly process of collecting, storing, processing and transmitting information in the interests of achieving the goal set for the information system using computer information technology. A fundamental element of any information system is a database or knowledge base. The meaning of database intends to the collection of interconnected structured data. Recently, the relational databases got most widely used, which is presented to the user as a collection of tables [6].

\section{OVERVIEW OF INFORMATION SYSTEMS IN EDUCATION}

A regional information system for automating the activities of organizations and regional institutions in the field of education has been developed and is being used already in many foreign countries, also in the Russian Federation. This information system allows the collection of information from educational institutions in the region following the forms of federal-state statistical monitoring; monitoring the performance of educational institutions, automation of the preparation of reports and statistical information, increasing the efficiency of fulfilling requests about the current state of educational institutions, automation of certification processes for pedagogical and managerial personnel, accreditation of educational institutions, automation of monitoring student performance and attendance, the provision of "electronic services" and the organization of "electronic" interagency interaction [1], [10].

Also, in the framework of the implementation of the national project "Education", the concept of information and analytical system for managing the entire processes of the university has been formulated and tested at the Scientific and research technological university. Following the concept, an information-analytical system for supporting the educational process and scientific research under the name AIS "Aksioma" was developed and implemented. AIS "Aksioma" includes the following functional modules: admissions office; student contingent management, current performance, current attendance, performance in final exams, documents issuance, educational plans, discipline programs, educational process planning, teachers workload (planning), schedule and classroom fund [8], [9].

Besides, most universities have implemented their information systems such as [5]:

IS "Management of the quality of the educational process. Accounting for academic performance and attendance" of the Samara State Technical University allows to record and analyze student performance and attendance; formation and maintenance of a list of specialities and disciplines of the entire university, prompt receipt of relevant information in automatic mode and maintaining the relevance of documents. AIS "University" of Stavropol State University provides to: conduct general monitoring of the activities of the university; quality management of the educational process, storage and processing of information about students and university employees, scientific and methodological activities of employees, calculation of class hours, distribution of study load and classroom fund, the formation of the schedule of training sessions and examination sessions, storing allRussian and university classifiers and reference books.

IS "Univeris" of the South Ural State University provides an opportunity to conduct various types of planning, storage and adjustment of curricula, storing lists of applicants and students enrolled in the educational program, accounting performance, registration of students transferred and not transferred to the next course, storing and changing student data, load planning, planning and scheduling training activities, accounting for student tuition, storing data on the placement of students in the dormitory, storage and adjustment of the expenditure side of the budget for remuneration, salary data management, tracking data on holidays, registration of vacation days, storing data on the schedule of working hours, storage of information on the procedures for rewarding and encouraging university employees.

Recently, university professors have also been trying to create and implement proprietary software tools that reflect a certain subject area. For example, in the educational process of a higher educational institution for the study of Information technologies, it provides for the solution of problems of several levels, such as the use of information technology as an educational tool, information technologies in professional activities, their theory, components and methods, training in applied information technologies focused on specialities [7]. 


\section{THE CONCEPTUAL MODEL OF THE HEMIS OF THE REPUBLIC OF UZBEKISTAN}

The implementation of the information system in the educational process of higher educational institutions covers the whole range of tasks related to the educational and scientific process. With the introduction of the system, it will be possible to organize an electronic exchange of educational and administrative data between higher educational institutions and the Ministry of higher and secondary special education of the Republic of Uzbekistan.

The creation and implementation of a higher education management information system are carried out in two stages [3]:

1. modernization of the ICT infrastructure of HEI and the Ministry to support the HEMIS;

2. development and implementation of an information system for higher education management.

The modernization of the ICT infrastructure of HEI will increase the productivity of the server platform to ensure the efficiency of the information service, and also provide students and faculty with unlimited access to internal and external educational information resources and services. The formation of the HEMIS allows to automate the administrative, economic and educational activities of the university, provide modern electronic services for teachers and students, create information and educational corporate portal of the university.

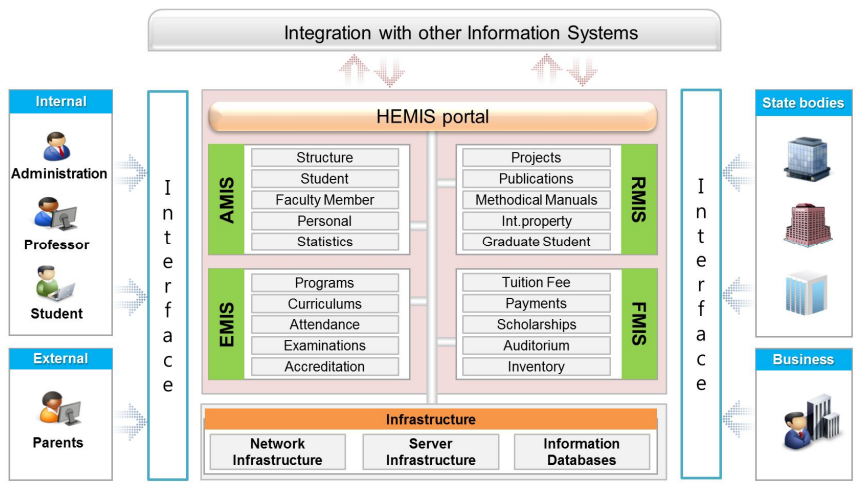

Figure 1: Conceptual model of the HEMIS information system

The implementation of the HEMIS will allow:

- prompt plan and manage the educational and scientific activities of HEI,

- automation of the administrative and economic activities of universities,

- providing information support for decision-making in all major areas of activity,

- forming the operational and external reporting,

- providing students with the opportunity to receive quality educational services at the level of modern requirements of national and international standards, regardless of the place of residence and study using modern ICT.

The main functional capabilities of the system are accounting and monitoring the contingent of students and teachers, organization of the educational process and monitoring of academic activities of students, accounting and monitoring of scientific work, accounting and monitoring of payment of scholarships and tuition fee, as well as the provision of interactive online services for students.

The conceptual model of the HEMIS consists of four main information subsystems as shown in Figure 1 [3]:

- AMIS - administrative management information system

- EMIS - Education management information system

- RMIS - Research management information system

- FMIS - financial management information system

The basic architecture of the HEMIS serves to integrate the information subsystems of AMIS, EMIS, RMIS and FMIS to provide students with educational information services based on a single access point.

The information system for the management of administrative activities serves to manage internal administrative business processes, such as: managing the contingent of staff, teachers and students, monitoring the administrative activities of the university. The information system for the management of the educational process serves to automate the processes of planning the educational process, managing curricula and disciplines, accounting for students' academic activities, and accounting for university graduates. The information system for the management of scientific activities is aimed at providing information and organizational support for the processes of accounting and planning research, publications, intellectual property and the training of highly qualified personnel. The information system for the management of financial activities is aimed at automating the processes of planning and controlling scholarship payments, as well as accounting for student tuition.

To work in a multi-user mode, the information system provides for various categories and roles of users, such as administrative and managerial personnel, teachers, students, parents, representatives of government agencies and business entities. Each category of users is provided with a personal account through which they receive the opportunity to use the information resources of the information system. There are an authorization system and the possibility of restricting user access to the system.

The reliability of the information system depends on the principle of organizing the network infrastructure, server infrastructure and database infrastructure. Moreover, the architecture of the information system is based on the concept of a three-tier client-server architecture. The client and server are information system software. Usually, these programs are located on different computers and interact with each other through a computer network using network protocols. With this architecture, the database server located on the server computer provides the bulk of the data processing. The client application generates queries to the database server, usually in the form of SQL language instructions. The server extracts the requested data from the database and transfers it to the client computer. At the same time, the network bandwidth and the performance of this computer, on which the information system is running, should be high depending on the number of users. The main advantage of this approach is a significantly smaller amount of transmitted data. 


\section{INFORMATION PROCESSES AND SYSTEM MODULES}

The information system is a repository of information, equipped with procedures for entering, searching and storing, and issuing information. The presence of such procedures is the main feature of information systems that distinguish them from simple clusters of information materials. Each such procedure is an information process that is a process of obtaining, creating, collecting, processing, accumulating, storing, searching, disseminating and using information.

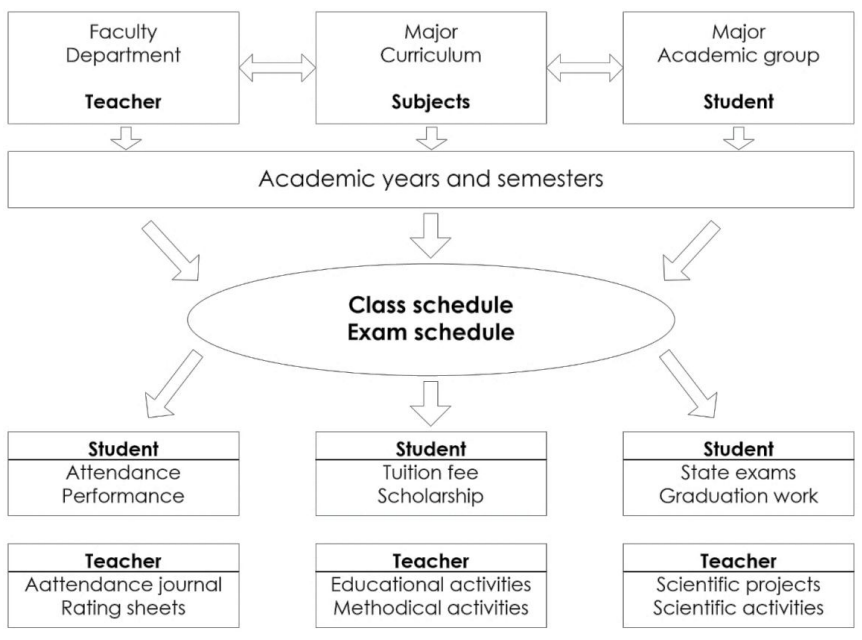

Figure 2: Information processes in the HEMIS

The following initial information processes exist in the HEMIS information system (Figure 2):

- formation and management of the contingent of teachers by taking into account faculties and departments;

- formation and management of the students' contingent by taking into account the areas of education and academic groups;

- formation and management of blocks of subjects by taking into account educational areas and curricula;

- formation and management of information on periods of academic years and semesters.

The main core of the information system processes is the class schedule and exam schedule (Figure 2). Teachers conduct training sessions and record student attendance for classes in the attendance journal based on the class schedule. Based on the examination schedules, rating sheets are kept, where students' performance is noted, as well as state exams and graduation defence are conducted.

Reports on attendance for classes, academic performance in subjects, payment of scholarships, payment of contracts, the results of passing state exams and protection of final works, as well as for teachers, electronic journals of student attendance for classes and rating reports on academic performance will be generated students in subjects, reports on educational and methodical works, scientific projects and publications are generated for students in the HEMIS information system.

The organization of the structure of the higher educational institution and the formation of the contingent of teachers are carried out following the processes as shown in Figure 3.

The module for managing the organizational structure of the HEI information system is built in such a way that faculties and departments with dynamic amounts can be formed in the system. This feature of the system makes it suitable for use in universities of various fields. The formation of the contingent of teachers is carried out according to the principle of "faculty - department - teacher". In the information system, teachers can be registered for the departments as the full time, on internal part-time jobs, on external part-time jobs and a per-hour basis.

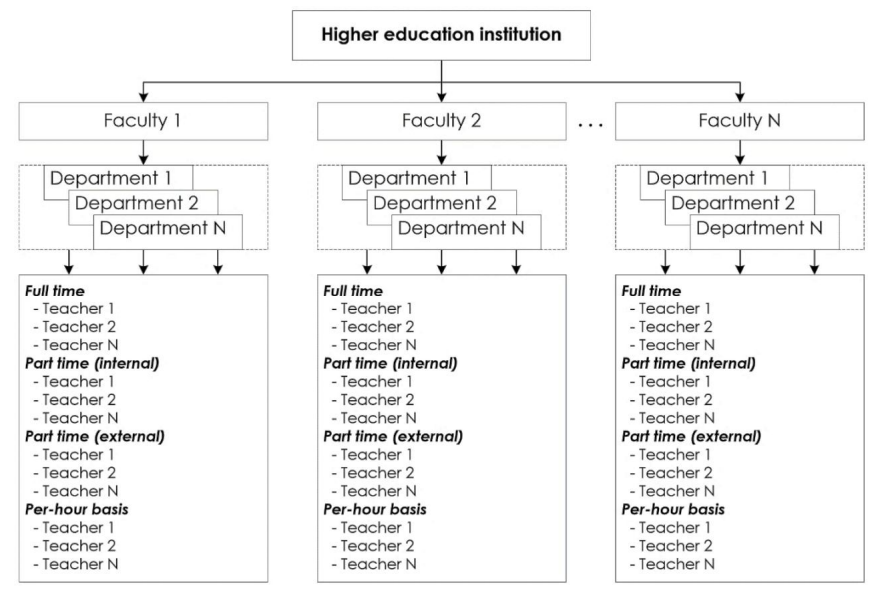

Figure 3: Formation of the organizational structure of HEI in HEMIS

Information about the contingent of students of a higher educational institution is formed following the structure shown in Figure 4.

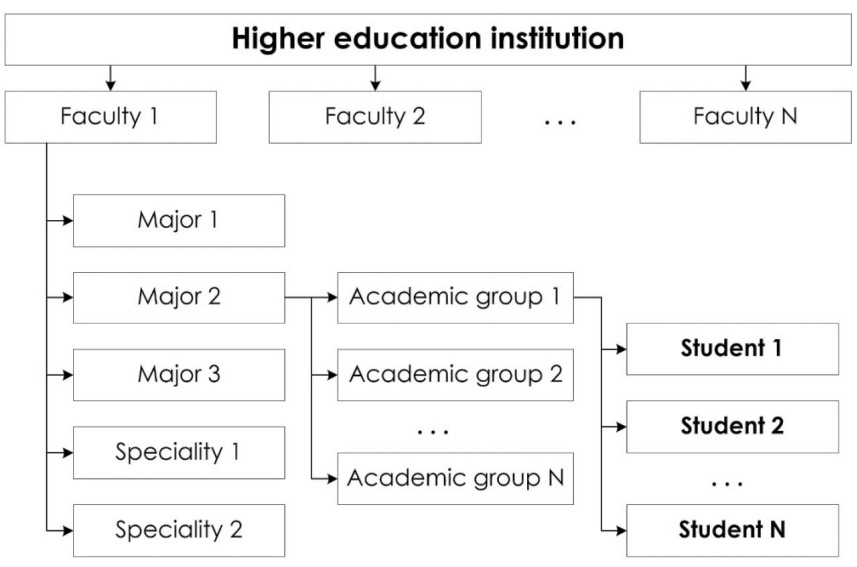

Figure 4: The formation of the student body in the HEMIS

Following the organizational structure of the university are formed based on the corresponding major of undergraduate education, specialities of masters and doctoral studies of the faculties. Here the number of areas of education and specialities are also dynamic. Since in different universities there may be different types and number of areas of education and specialities. The formation of the contingent of students is carried out based on academic groups according 
to the principle of "faculty - academic programs (major and speciality) - academic group - student". That is, within the areas of education and specialities, academic groups are formed with a unique number and name, consisting of certain numbers of students following the normative documents of higher education.

Besides, for scheduling classes, accounting for attendance and student achievement, it is necessary to enter into the system information on curricula, subjects and extracurricular academic activities of students following the structure that shown in Figure 5.

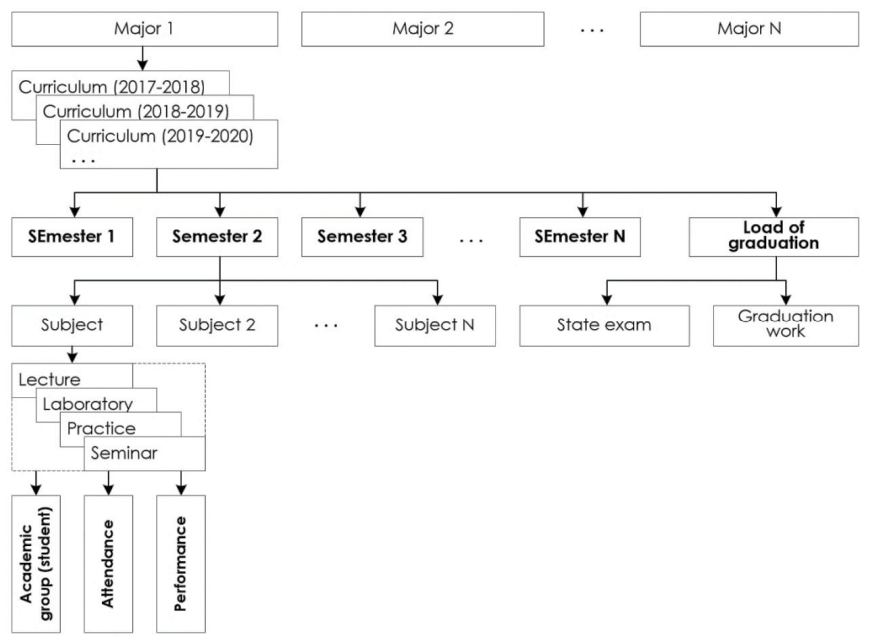

Figure 5: Formation of curricula and subjects in HEMIS

Regarding the normative documents of higher education, curricula are drawn up and approved for individual areas of education and speciality. Curricula are created separately in the system for the entire period of the educational process to ensure the independence of students' academic data for each year of admission. Thus, in a separate major of education, there can be many independent curricula for each admission code.

Both in the curriculum template and the information system, subjects are formed according to the academic semesters. That is, school years are divided into academic semesters, and subjects are distributed between these semesters. Depending on the nature of the curriculum, in the system, they can include subjects with a different number of hours following the standards. Additionally, in the curriculum there are certain types of training loads that do not apply to individual semesters, they are state exams and final works (for graduation).

By the specifics of the disciplines, each subject has various types of classes, such as lecture, laboratory, practical and other classes. These types of classes are taken into account in the preparation of curricula and class schedules and have certain academic loads. Accounting for student attendance and academic performance is carried out based on attendance journals and a rating report of academic performance, which is formed for individual academic groups of students in each subject.

\section{EXPECTED RESULTS AND INFORMATION SERVICES}

As part of the project, a unified higher education management information system, as well as a database of students and teachers will be created. As part of the implementation of the system, the following information services will be created for students and teachers: Management of educational areas, Specialty management, Academic group management, Student contingent management, Curriculum and subject management, Schedule management Exam management, Student performance management, Management of the activities of teachers, Management of contracts for studies, Manage documents and reports.

The higher education management information system is a platform as an independent application, which includes: "Presentation level" - a user interface to provide users with access to system functions, "Business logic level" - a set of software services that are executed on an application server and implement all business logic, "Data level", which will be implemented based on industrial DBMS and data storage network, "Level of integration" - the interaction between the components of the HEMIS and related systems.

As the result, the HEMIS will be able to link data transfer between the most important stakeholders of the higher education system and will improve the quality of education and facilitate effective decision-making at the institutional and central level.

\section{ACKNOWLEDGMENT}

This research was supported by the World Bank and Ministry of higher and secondary specialized education of the Republic of Uzbekistan (P128516), and the project with the title of "Strengthening higher education management", a part of the complex project titled "Modernizing Higher Education"

\section{REFERENCES}

[1] А.Н.Немцев, Р.А.Загороднюк,

А.И.Штифанов, С.Н.Немцев,

В.А.Беленко, Проектирование автоматизированной информационной системы мониторинга деятельности образовательных учреждений и предоставления «Электронных услуг» в сфере образования. // Журнал Научные ведомости Белгородского государственного университета. Том. 19, №13-1 (108), - 2011, - С. 150-160.

[2] Постановление Президента Республики Узбекистан “О мерах по дальнейшему развитию системы высшего образования”. г.Ташкент, 20 апреля 2017 г., № ПП-2909

[3] Abdullaev A., Khamdamov U. The concept of development of information systems and services in the system of higher education of the Republic of Uzbekistan. // EU-01-002070 "Asian Intellectual Property" LLC, 2018. Available at: https://interoco.com/all-materials/literary-work/2364-2018-1130-10-41-59.html

[4] J.Elov, U.Khamdamov, O.Makhmanov. The data structure and information model for the information system of monitoring 
the educational process in the medical field. // 2019 International Conference on Information Science and Communications Technologies (ICISCT), Available at: https://ieeexplore.ieee.org/abstract/ document/9012053

[5] Сенькин В.В. Возможности информационных систем в управлении образованием. // Вестник Южно-Уральского государственного университета. - 2012. - № 41(300). - С. 42-45

[6] Горюнов В. С. Информационные системы в образовании // Молодой ученый. - 2010. - №5. Т.2. - С. 159-161.

[7] Аксюхин А.А. Вицен А.А. Мекшенева Ж.В. Информационные технологии в образовании и науке. // Журнал Современные наукоемкие технологии. - 2009. № 11 - С. $50-52$

[8] Иванченко Д.А. Оптимизация построения информационной системы управления вузом: концептуальные подходы. // Журнал Университетское управление: практика и анализ. - 2011, - №2, - С. 40-48

[9] Коваль Наталья Николаевна. Современные информационно-коммуникационные технологии в аналитической управленческой деятельности: проблемы и перспективы. // Карельский научный журнал. - №1(10), 2015, - C. 39-44.

[10] Karakozov Sergey D., Ryzhova Natalia I. Information and education systems in the context of digitalization of education // Журнал СФУ. Гуманитарные науки. - 2019. №9.

[11] Sultanov, D. (2019). Strategies for Improving Education Services through Collective Value Creation (Doctoral dissertation, 서울대학교 대학원).

[12] Sultanov, D., Kim, K., \& Altmann, J. (2018, September). Snooping Around a Fence: A Lesson from the Education Sector in a Software Service Ecosystem. In International Conference on the Economics of Grids, Clouds, Systems, and Services (pp. 66-76). Springer, Cham.

[13] Bekmurodovich, E. J., Rakhmatillayevich, K. U., Bakhodirovich, S. D., \& Qudratovich, M. O. (2020). Structure of functional processes and information model of e-referral module of the system for medical personnel retraining. International Journal of Scientific and Technology Research, 9(5), 207-211. Retrieved from www.scopus.com

[14] F. Salimovna, 'Improving the structure and modelinteraction of information processes on distance learning', International Journal of Advanced Trends in Computer Science and Engineering, vol. 9, pp. 4043-4048, Jun. 2020, doi: 10.30534/ijatcse/2020/230932020.

[15] S. Allahawiah, 'The Utilization of Education Management Information System (EMIS) to Predict Future Maintenance Plans for Buildings: A Case Study of Karak Governorate Schools', International Journal of Advanced Trends in Computer Science and Engineering, vol. 8, pp. 2492-2506, 2019, doi: 10.30534/ijatcse/2019/95852019. 